\title{
Trends and Overall Growth Analysis of Cashewnut Cultivation in Kerala
}

\author{
N Karunakaran *
}

\section{Abstract}

Even in the $21^{\text {st }}$ century, agriculture is the major source of livelihood for majority of Indian population. But agricultural sector is under the big threat of economic reforms like liberalization and modernization of economy. The agrarian economy of Kerala could not exclude from the drastic hitting of the liberalization, privatization and globalization reforms; farmers of the state began to think that there is no other way to sustain their life. Cashewnut is one of the major cash crop became the victim of Liberalization, Privatization and Globalization (LPG) reforms. The export of agricultural produce make it difficult to get a better price for cashewnut and so many diseases are also contributing in the crisis of this cultivation. The area under cashew cultivation has started coming down over the years and the decline in area and yield growth rate was responsible for the negative growth rate in production for cashewnut and the share of real components is negative for the overall growth of output of this crop compared to monetary components and unless there are concerted efforts by the government to create awareness among cashew growers on scientific cultivation methods, there will be a conversion of cashew plantations into rubber plantations.

Keywords: Growth trend, Cashewnut, Crop output, Overall growth, Real growth, Monetary growth.

\footnotetext{
* Assistant Professor in Economics, PG Department of Economics, EKNM Government College Elerithattu, Elerithattu - Post, Nilishwar, Via, Kasaragod Dist, Kerala, India; narankarun@gmail.com
} 


\section{Introduction}

The agricultural scenario in Kerala continues to be the most important and single largest sector of the state's economy in terms of income and employment. In spite of the significant advances in industrial and service sectors, agriculture continues to be the largest provider of employment and livelihood both at the national and state levels.

The share of agriculture in net state domestic product declined from 56 percent in 1960-61 to 9.20 percent in 2009-10. But the sector plays an important role in the Kerala economy as it continues to engage around two-fifth of the population. One of the major changes that have been taking place in Kerala is the gradual shifting of areas from food crops like rice and tapioca to plantation crops like coconut, rubber, coffee, etc (Lakshmi KR and Pal TK, 1988). The reduction in area under food crops in Kerala from 40.43 percent in 1970-71 to 18.74 percent in 1992-93 and 16.52 percent in 2002-03 is a phenomenon happened very rarely in any state (Mani $\mathrm{KP}$, 2009). Present trend reveals that Kerala is being converted to non-food crop area and the ratio of food crop to non-food crop area is $12: 88$. The main feature of the present trend is change in the cultivated area under food grain crops to non-food grain crops and change in the cultivated area under one non-food grain crop to another non-food grain crops.

Kerala initiated the efforts for the development of cashewnut during the Third Five-Year Plan period. The development of cashewnut during this period was taken up in the lands vested with the government by the Department of Agriculture and Forest. The private sector development measures were started in 1972 by the Department of Agriculture. In 1970-71, Kerala had 1, 02711 hectare of land under cashew cultivation, with an annual production of 1, 15240 tonnes of raw nuts.

In Kerala cashew cultivation has been declining over the years. In 2010-11, the area fell by almost one - third of this in 1970-71 and the output by over 79 percent. The area under the crops which touched an all time high of around 1.55 lakh hectare by the end of $7^{\text {th }}$ plan has come down to one lakh hectare by the end of $8^{\text {th }}$ plan and it is below 50000 hectare at present. The sustainability of the 32 
crop in Kerala is in real threat on account of the surging pressure for replacement with rubber. In this context, an overview of cashewnut cultivation in Kerala in terms of trends and overall growth analysis is worked out.

\section{Materials and Methods}

The materials used in this study were from secondary data sources and were collected from various publications of the Government of Kerala like Economic Review, Statistics for Planning, Agricultural Statistics and Season and Crop Reports; Food and Agriculture Organization; Cashew and Cocoa statistics of Government of India, etc.

For measuring the growth trends of area, production and productivity of cashewnut crops in Kerala Compound Growth Rates (CGR) of area, production and productivity was estimated with the following exponential model.

$\mathrm{Y}=a b^{t}$

The growth rate (GR) has been computed using the formula:

GR $=($ Antilog b-1)100

The $\mathrm{F}$ test has been applied to test the significance of $\mathrm{b}$.

To measure the overall growth of output (real and monetary) for the cashewnut crop during different periods in Kerala, the methodology used by Kurian CT and Joseph James (1979) and Kaushik KK (1993) is applied in this study.

Observing the value of output of cashewnut crop in Kerala in period zero $\left(\mathrm{V}_{0}\right)$ and in period $\mathrm{t}\left(\mathrm{V}_{\mathrm{t}}\right)$, the difference between the two is decomposed into eight component elements, viz, (i) change in area, (ii) change in yield per hectare, (iii) change in cropping pattern, (iv) the interaction between yield and cropping pattern, (v) the price change effect, (vi) the interaction between price and yield, (vii) interaction between price and cropping pattern effect and (viii) interaction between price, cropping pattern and yield.

If $V_{0}$ and $V_{t}$ will represent the value of output in the two periods and $A_{0}$ and $A_{t}$ will denote gross cropped area in years 0 and $t$ respectively, then by definition, 
$\mathrm{V}_{0}=\mathrm{A}_{0} \Sigma_{\mathrm{i}} \mathrm{Wi}_{0} \mathrm{Ci}_{0} \mathrm{yi}_{0}$

$\mathrm{V}_{\mathrm{t}}=\mathrm{A}_{\mathrm{t}} \Sigma_{\mathrm{i}} \mathrm{wi}_{\mathrm{t}} \mathrm{ci}_{\mathrm{t}} \mathrm{yi} \mathrm{i}_{\mathrm{t}}$

Terminal period output valued at base year prices can be said to represent the 'real output' of the terminal year to be denoted by $\mathrm{P}_{\mathrm{t}}$. That is,

$\mathrm{P}_{\mathrm{t}}=\mathrm{A}_{\mathrm{t}} \sum_{\mathrm{i}} \mathrm{wi}_{0} \mathrm{Ci}_{\mathrm{t}} \mathrm{yi}$

The difference in the value of aggregate output $\left(\mathrm{V}_{\mathrm{t}}-\mathrm{V}_{0}\right)$ can be disaggregated into its 'real' and 'monetary' components with the help of the concept:

$\mathrm{V}_{\mathrm{t}}-\mathrm{V}_{0}=\left(\mathrm{V}_{\mathrm{t}}-\mathrm{P}_{\mathrm{t}}\right)+\left(\mathrm{P}_{\mathrm{t}}-\mathrm{V}_{0}\right)$

The first term on the right hand side

$V_{t}-P_{t}=A_{t} \sum_{i} W i_{t} c i_{t} y i_{t}-\sum_{i} w i_{0} c i_{t} y i_{t}$

is the difference between the terminal year aggregate output valued in terms of terminal year prices $\left(w i_{t}\right)$ and base year prices $\left(w i_{0}\right)$, and hence can be thought of as a measure of the monetary component in increase in output.

The second term

$\mathrm{P}_{\mathrm{t}}-\mathrm{V}_{0}=\mathrm{A}_{\mathrm{t}} \Sigma_{\mathrm{i}} \mathrm{wi}_{0} \mathrm{Ci} \mathrm{i}_{\mathrm{t}} \mathrm{yi} \mathrm{i}_{\mathrm{t}}-\mathrm{A}_{0} \sum_{\mathrm{i}} \mathrm{Wi}_{0} \mathrm{i}_{0} \mathrm{yi} \mathrm{i}_{0}$

is the difference between 'real output' in the terminal year and 'real output' in the base year, and hence can be said to be a measure of the real component in increase in output.

$\left(\mathrm{P}_{\mathrm{t}}-\mathrm{V}_{0}\right)$ can be decomposed as shown below. That is,

$$
\left(\mathrm{P}_{\mathrm{t}}-\mathrm{V}_{0}\right)=\left(\mathrm{A}_{\mathrm{t}}-\mathrm{A}_{0}\right) \sum_{\mathrm{i}} \mathrm{wi}_{0} \mathrm{ci}_{0} \mathrm{yi}_{0}
$$

$+\mathrm{A}_{\mathrm{t}} \sum_{\mathrm{i}} \mathrm{Wi} \mathrm{i}_{0} \mathrm{Ci}_{0}\left(\mathrm{yi} \mathrm{i}_{\mathrm{t}}-\mathrm{yi}\right)$

$+\mathrm{A}_{\mathrm{t}} \sum_{\mathrm{i}} \mathrm{Wi} \mathrm{i}_{0} \mathrm{yi}_{0}\left(\mathrm{ci}_{\mathrm{t}}-\mathrm{ci}_{0}\right)$

$+\mathrm{A}_{\mathrm{t}} \Sigma_{\mathrm{i}} \mathrm{wi}_{0}\left(\mathrm{yi}_{\mathrm{t}}-\mathrm{yi} \mathrm{i}_{0}\right)\left(\mathrm{ci}_{\mathrm{t}}-\mathrm{ci}_{0}\right)$

In the decomposition scheme (1) above, the first term on the right hand side is the area effect, the second the yield effect, the third the cropping pattern effect and the fourth interaction effect, representing the interaction between yield and changes in cropping pattern. The term 'area effect' reflects the impact of growth of 34 
average area on the increase in the level of production, keeping all other influences inoperative during the period. 'Yield effect' reflects the impact of the growth of average yield and the 'cropping pattern effect' reflects the impact of cropping pattern changes during the current period as compared to the base period. The interaction effect' between yield and cropping pattern signifies the influence of these factors over the others in bringing about the changes in production. The above decomposition scheme (1) shows the disaggregation of the real component.

A decomposition of the monetary component is shown in scheme (2) below:

$$
\begin{aligned}
& \mathrm{V}_{\mathrm{t}}-\mathrm{P}_{\mathrm{t}}=\mathrm{A}_{\mathrm{t}} \Sigma_{\mathrm{i}} \mathrm{ci}_{0} \mathrm{yi} \mathrm{i}_{0}\left(\mathrm{wi}_{\mathrm{t}}-\mathrm{wi}_{0}\right) \\
& +\mathrm{A}_{\mathrm{t}} \sum_{\mathrm{i}} \mathrm{ci}_{0}\left(w \mathrm{wi}_{\mathrm{t}}-\mathrm{wi} \mathrm{i}_{0}\right)\left(\mathrm{yi} \mathrm{i}_{\mathrm{t}}-\mathrm{yi} \mathrm{i}_{0}\right) \\
& +\mathrm{A}_{\mathrm{t}} \sum_{\mathrm{i}} \mathrm{yi} \mathrm{i}_{0}\left(w \mathrm{wi}_{\mathrm{t}}-\mathrm{wi} \mathrm{i}_{0}\right)\left(\mathrm{ci}_{\mathrm{t}}-\mathrm{ci}_{0}\right) \\
& +\mathrm{A}_{\mathrm{t}} \sum_{\mathrm{i}}\left(\mathrm{wi}_{\mathrm{t}}-\mathrm{wi} \mathrm{i}_{0}\right)\left(\mathrm{ci} \mathrm{i}_{\mathrm{t}}-\mathrm{ci} \mathrm{i}_{0}\right)\left(\mathrm{yi} \mathrm{i}_{\mathrm{t}}-\mathrm{yi} \mathrm{i}_{0}\right)
\end{aligned}
$$

The first component in the scheme (2) is the 'pure price effect', that is, in the absence of any change in the total output (cioyio is total output of the $i^{\text {th }}$ crop (cashewnut)) an increase of this magnitude in the value of output is solely due to rise in prices. The second and third terms are respectively the first order interactions between price and yield rate and price and cropping pattern effect, under constant cropping pattern and constant yields. These effects signify the influence of any of the two factors over the other in bringing about changes in production. The last term is the second order interaction term between the three variables considered, viz, changes in prices, cropping pattern and yields and may be called the 'total interaction effect'.

The variables and notations used in the model are:

A0 $=$ Gross cropped area in base year zero (0),

$\mathrm{At}=$ Gross cropped area in terminal year $(\mathrm{t})$,

$\mathrm{V} 0=$ Value of output in period zero (0),

$\mathrm{Vt}=$ Value of output in period $\mathrm{t}$,

$\mathrm{Pt}=$ Real output of the terminal year $(\mathrm{t})$,

$\mathrm{ci}_{0}=$ Proportion of the area of the $\mathrm{ith}^{\text {th }}$ crop (cashewnut) in Gross cropped area in the base year, $\mathrm{yi}_{0}=$ Yield of the $\mathrm{i}^{\text {th }}$ crop (cashewnut) in the base year, 
$\mathrm{wi}_{0}=$ Farm harvest price of the $\mathrm{i}^{\text {th }}$ crop (cashewnut) in the base year,

$\mathrm{ci}_{\mathrm{t}}=$ Proportion of the area of the $\mathrm{i}^{\text {th }}$ crop (cashewnut) in the terminal year $(\mathfrak{t})$,

$y i_{t}=$ Yield of the $i^{\text {th }}$ crop (cashewnut) in the terminal year $(t)$,

$w i_{t}=$ Farm harvest price of the $i^{\text {th }}$ crop (cashewnut) in the terminal year $(\mathfrak{t})$.

The subscript ' 0 ' and ' $t$ ' refer respectively to the base year and terminal year. Subscript ' $i$ ' is used for the $i^{\text {th }}$ crop (cashewnut). The trend and overall growth analysis of cashewnut crop in Kerala was done from 1960-61 to 2009-10 considering five sub-periods (since the period can be broken up in different ways, and the result will vary accordingly, decade wise classification of the entire period into five sub-periods was undertaken).

\section{Results and Discussion}

Cashew is grown mainly in peninsular India for its fruits as well as for its nuts, but mainly for the latter. Cashew is essentially a tropical crop, grows best in the warm, moist, and typically tropical climate, with a well-defined dry season of at least $4-5$ months. Areas where the temperature ranges from 20 to 30 degree Celsius with an annual precipitation of $1000-2000 \mathrm{~mm}$ are ideal for cashew growing. Heavy rainfall, evenly distributed throughout the year, is not favourable though the trees may grow and sometimes set fruit. It needs a climate with a well defined dry season of at least four months to produce the best yield. Coincidence of excessive rainfall and high relative humidity with flowering may result in flower or fruit drop and heavy incidence of fungal disease. Cashew is regarded as "essentially coastal tree" but that is not true. It also grows well at considerable distance from the coast (Nair MK, et.al, 1979).

Commercial cultivation of cashew in India is taken up mainly in eight states and is cultivated in small areas in other states of the country also. India has an area of about 9.23 lakh hectares under cashew with an estimated annual production of about 6.13 lakh tonnes of raw cashewnut. The country is the largest producer, processor, consumer and exporter of cashewnut in the world. A large number of small and marginal farmers, especially living on the coastal belts of India, depend on cashew for their livelihood. 
Nearly 2.00 lakh workers, more than 90 percent of whom are women, directly employed in cashew processing factories which are concentrated mostly in Kerala. It is estimated that nearly two million people are involved, directly and indirectly in cashew cultivation, processing and marketing. The important cashew growing states of India are Andrapradesh, Goa, Karnataka, Kerala, Maharashtra, Orissa and Tamilnadu. The general notion is that "cashew is very modest in its soil requirements and can adapt itself to varying soil conditions without impairing productivity". But cashew performs much better on good soils than on poor soils. The best soils for cashew are deep, friable well drained sandy loans without a hard pan. Cashew also thrives on pure sandy soils although mineral deficiencies are more likely to occur. Water stagnation and flooding are not congenial for cashew (Prasad Rao, 2002).

Today, cashewnut form an important part of everyday meal in several countries of the world. Cashewnut is a major commercial crop in India also which earns considerable foreign exchange. Unfortunately, production and productivity of cashew has been remaining low despite consistent developmental efforts.

Table 1: Global Production of Cashewnut (2009 - 2010)

\begin{tabular}{|c|l|c|c|}
\hline $\begin{array}{c}\text { Sl. } \\
\text { No. }\end{array}$ & $\begin{array}{c}\text { Name of } \\
\text { countries }\end{array}$ & $\begin{array}{c}\text { Production } \\
\text { (In Million Tonnes) }\end{array}$ & $\begin{array}{c}\text { Yield (In Million } \\
\text { Tonnes/Hectare) }\end{array}$ \\
\hline 1 & Nigeria & 650,000 & 1.97 \\
\hline 2 & India & 613,000 & 0.66 \\
\hline 3 & Cote d'Ivoire & 380,000 & 0.44 \\
\hline 4 & Vietnam & 289,842 & 0.85 \\
\hline 5 & Indonesia & 145,082 & 0.25 \\
\hline 6 & Philippines & 134,681 & 4.79 \\
\hline 7 & Brazil & 104,342 & 0.14 \\
\hline 8 & Guinea- & 91,100 & 0.38 \\
\hline 9 & Bissau & 80,000 & 1.0 \\
\hline 10 & Banzania & 69,700 & 0.29 \\
\hline 11 & World Total & $2,757,598$ & 0.58 \\
\hline
\end{tabular}




\section{(a) Global Scenario of Cashew Cultivation}

India is the second largest producer of cashew in the world with 22 percent share after Nigeria (24 percent). The other important producers were Cote d'Ivoire (14 percent), Vietnam (11 percent) and Indonesia (5 percent). Cashewnut is produced in almost 32 countries of the world and now it has become the number one crop in the world. Table.1 reveals that the world production figures of this crop cover around 27.5 lakh Million tonnes per year. The major raw cashew producing countries along with their production figures in the world are Nigeria (650,000 Million tonnes), India (613,000 Million tonnes), Cote d'Ivoire (380,000 Million tonnes), Vietnam (289,842 Million tonnes) and Indonesia (145,082 Million tonnes).

Table: 2 Area, Production and Productivity of cashewnut in India

\begin{tabular}{|c|c|c|c|}
\hline Year & $\begin{array}{c}\text { Area } \\
\text { (in '000 } \\
\text { hectare) }\end{array}$ & $\begin{array}{c}\text { Production } \\
\text { (in'000 Million tonnes) }\end{array}$ & $\begin{array}{c}\text { Productivity } \\
\text { (in Kg/hectare) }\end{array}$ \\
\hline $1987-88$ & 527.4 & 260.3 & 493.55 \\
\hline $1988-89$ & 529.3 & 274.3 & 518.22 \\
\hline $1989-90$ & 530.9 & 285.6 & 537.95 \\
\hline $1990-91$ & 531.9 & 294.6 & 553.86 \\
\hline $1991-92$ & 533.5 & 305.3 & 572.26 \\
\hline $1992-93$ & 560.3 & 349.4 & 623.59 \\
\hline $1993-94$ & 565.4 & 348.1 & 615.67 \\
\hline $1994-95$ & 589.0 & 371.2 & 630.22 \\
\hline $1995-96$ & 652.0 & 417.8 & 640.80 \\
\hline $1996-97$ & 659.0 & 430.0 & 652.50 \\
\hline $1997-98$ & 701.0 & 360.0 & 513.55 \\
\hline $1998-99$ & 732.0 & 460.0 & 628.42 \\
\hline $1999-00$ & 686.0 & 520.0 & 758.02 \\
\hline $2000-01$ & 720.0 & 450.0 & 625.00 \\
\hline $2001-02$ & 750.0 & 470.0 & 626.67 \\
\hline $2002-03$ & 770.0 & 500.0 & 649.35 \\
\hline $2003-04$ & 730.0 & 535.0 & 732.88 \\
\hline $2004-05$ & 820.0 & 544.0 & 810.00 \\
\hline $2005-06$ & 837.0 & 573.0 & 815.00 \\
\hline $2006-07$ & 854.0 & 620.0 & 860.00 \\
\hline $2007-08$ & 868.0 & 665.0 & 778.00 \\
\hline $2008-09$ & 893.0 & 695.0 & 6900 \\
\hline $2009-10$ & 923.0 & 613.0 & \\
\hline & & & \\
\hline
\end{tabular}

Source:- About Cashew and Cocoa statistics (2011), Government of India, New Delhi. 
In the early 1970 's, the majority of global cashewnut production (68 percent of total) took place in African countries, in particular, Mozambique and Tanzania. Over the following thirty years, production trends shifted with Asian countries emerging as the world leaders in cashewnut production. Today, India and other Asian countries, particularly, Vietnam and Indonesia, are beginning to expand their production capacities.

\section{(b) Cashew Situation in India}

Cashew cultivation in India confines mainly to the peninsular areas. It is grown in Kerala, Karnataka, Goa, and Maharashtra along the west coast and Tamilnadu, Andrapradesh, Orissa, and West Bengal along the east coast. To a limited extent Madhyapradesh, Manipur, Tripura, Meghalaya and Andaman and Nicobar Islands also take part in the cultivation and production of cashewnut.

Table.3 Area, Production and productivity of cashewnut in different states of India (2009-10)

\begin{tabular}{|c|c|c|c|c|}
\hline $\begin{array}{l}\text { Sl. } \\
\text { No. }\end{array}$ & States & $\begin{array}{c}\text { Area } \\
\text { (in '000 } \\
\text { hectare) }\end{array}$ & $\begin{array}{c}\text { Production } \\
\text { (in '000 } \\
\text { Million tonnes) }\end{array}$ & $\begin{array}{l}\text { Productivity } \\
\text { (in } \\
\mathrm{Kg} / \text { hectare) }\end{array}$ \\
\hline 1 & Kerala & 49 & 37 & 744 \\
\hline 2 & Karnataka & 118 & 53 & 461 \\
\hline 3 & Goa & 55 & 26 & 473 \\
\hline 4 & Maharashtra & 175 & 198 & 1186 \\
\hline 5 & Tamilnadu & 133 & 60 & 472 \\
\hline 6 & Andrapradesh & 183 & 99 & 544 \\
\hline 7 & Orissa & 143 & 84 & 641 \\
\hline 8 & West Bengal & 11 & 10 & 909 \\
\hline 9 & Others & 56 & 46 & 680 \\
\hline \multicolumn{2}{|c|}{ Total } & 923 & 613 & 695 \\
\hline
\end{tabular}

Source: - About Cashew and Cocoa statistics (2011), Government of India, New Delhi

Table. 2 and 3 shows the area, production and productivity of cashewnut in India and in different states. Maharashtra is the highest producer with 1.98 lakh Million tonnes contributing 32 percent of the national production. Andrapradesh, which rank first in respect of area, is the second largest producer. The production in Andrapradesh is around 99,000 Million tonnes, is more than double 
to that of the production obtaining from Kerala. Orissa which rank third in area is third in respect of production with 84,000 Million tonnes which also is around more than double to that of the production of Kerala. Tamilnadu being the fourth rank holder in area is the fourth rank holder in respect of production with 60,000 Million tonnes. Karnataka ranking fifth in area is the fifth in production. In respect of productivity, Maharashtra ranks first $(1186 \mathrm{Kg} /$ hectare) closely followed by West Bengal and Kerala.

\section{(c) Cashew Cultivation in Kerala}

The state commands an important position in the production of cashewnut. It is one of the most important export oriented crops of Kerala and is a foreign exchange earner to the country. Table.4 and Figure.1 reveals the area, production and productivity of cashewnut cultivation in Kerala during 1960-61 to 2009-10.

Table.4. Area, production and productivity of cashewnut cultivation in Kerala

\begin{tabular}{|c|c|c|c|c|}
\hline $\begin{array}{c}\text { Sl. } \\
\text { No. }\end{array}$ & Year & $\begin{array}{c}\text { Area } \\
\text { (in '000 hectare) }\end{array}$ & $\begin{array}{c}\text { Production } \\
\text { (in'000 Million } \\
\text { tonnes) }\end{array}$ & $\begin{array}{c}\text { Productivity } \\
\text { (in Kg/hectare) }\end{array}$ \\
\hline 1 & $1960-61$ & 54.32 & 84.63 & 1558 \\
\hline 2 & $1963-64$ & 82.37 & 92.31 & 1122 \\
\hline 3 & $1967-68$ & 94.99 & 106.58 & 1122 \\
\hline 4 & $1970-71$ & 102.71 & 115.24 & 1122 \\
\hline 5 & $1973-74$ & 103.16 & 115.75 & 1122 \\
\hline 6 & $1977-78$ & 126.96 & 84.73 & 663 \\
\hline 7 & $1980-81$ & 141.30 & 81.90 & 580 \\
\hline 8 & $1983-84$ & 142.34 & 77.37 & 545 \\
\hline 9 & $1987-88$ & 121.60 & 81.48 & 670 \\
\hline 10 & $1990-91$ & 115.6 & 102.8 & 702 \\
\hline 11 & $1993-94$ & 106.7 & 87.5 & 749 \\
\hline 12 & $1997-98$ & 94.7 & 56.9 & 601 \\
\hline 13 & $2000-01$ & 92.1 & 66.2 & 718 \\
\hline 14 & $2003-04$ & 88.4 & 65.2 & 737 \\
\hline 15 & $2005-06$ & 80.72 & 68.26 & 872 \\
\hline 16 & $2006-07$ & 70.46 & 61.68 & 875 \\
\hline 17 & $2007-08$ & 58.38 & 52.40 & 898 \\
\hline 18 & $2008-09$ & 52.87 & 42.27 & 800 \\
\hline 19 & $2009-10$ & 49.00 & 37.00 & 744 \\
\hline
\end{tabular}

Source: - Computed from (i) Statistics for Planning (various issues), Department of Economics and Statistics, Govt. of Kerala, Thiruvananthapuram. (ii) Economic Review (various issues), State Planning Board, Govt. of Kerala, Thiruvananthapuram 
Table.5 shows that cashew cultivation has been showing a decreasing trend. The share of Kerala in the area under cashewnut in the country has come down recently. In 1960-61, area proportion of cashewnut in Kerala was in the sixth position, which improved to five in 1980-81 and in 2009-10 the position was decreased to nine; the decline in area from 1960-61 to 2009-10 was 2.66 percent. In all the districts except Palakkad negative change in the percentage of cashewnut area was observed during the period. After 2000-01 periods, cashew cultivation has been showing a decreasing trend in production and productivity also.

Table.5. Percentage Change in the Cultivation of Cashewnut Crops in Kerala in Different Periods

\begin{tabular}{|c|c|c|c|c|c|c|c|}
\hline $\begin{array}{l}\dot{2} \\
\dot{z} \\
\dot{m}\end{array}$ & Districts & 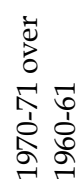 & 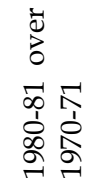 & 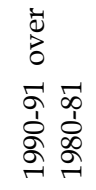 & 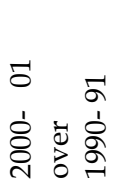 & 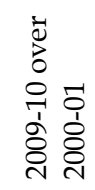 & 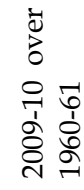 \\
\hline 1 & Thiruvananthapuram & -9.31 & 51.51 & -38.20 & -29.81 & -55.30 & -73.36 \\
\hline 2 & Kollam & 15.39 & -15.67 & -22.01 & -26.74 & -33.93 & -63.27 \\
\hline 3 & Pathanamthitta & - & - & - & -46.22 & -16.85 & -55.28 \\
\hline 4 & Kottayam & $\begin{array}{l}- \\
33.81 \\
\end{array}$ & -10.27 & -21.32 & -28.99 & -22.22 & -61.01 \\
\hline 5 & Alappuzha & 19.92 & 9.12 & 55.84 & -21.46 & -46.80 & -14.80 \\
\hline 6 & Ernakulam & 10.09 & -47.08 & -38.55 & -36.85 & -50.38 & -87.97 \\
\hline 7 & Idukki & - & - & -29.16 & 64.39 & 15.99 & 35.09 \\
\hline 8 & Trissur & $\begin{array}{l}- \\
14.44\end{array}$ & -5.75 & -21.30 & -30.37 & -27.49 & -67.96 \\
\hline 9 & Palakkad & $\begin{array}{l}193.1 \\
7 \\
\end{array}$ & 39.45 & -28.45 & -35.46 & -43.90 & 5.91 \\
\hline 10 & Malappuram & - & - & -23.87 & -30.52 & -45.05 & -70.94 \\
\hline 11 & Kozhikkode & 58.75 & -68.43 & -23.12 & -3.52 & -25.93 & -62.82 \\
\hline 12 & Wayanad & - & - & - & 105.35 & -26.24 & 51.47 \\
\hline 13 & Kannur & $\begin{array}{l}480.3 \\
2\end{array}$ & 80.65 & -53.97 & -12.51 & -30.23 & -49.24 \\
\hline 14 & Kasaragod & - & - & - & -17.35 & -42.94 & -52.84 \\
\hline 15 & State & 89.08 & 37.57 & -18.19 & -20.31 & -42.60 & -2.66 \\
\hline
\end{tabular}

Source: - Computed from (i) Statistics for Planning (various issues), Department of Economics and Statistics, Govt. of Kerala, Thiruvananthapuram. (ii) Economic Review (various issues), State Planning Board, Govt. of Kerala, Thiruvananthapuram 
In terms of their claim on total cropped area, the leading crops in the state in 1960-61 were rice, coconut, arecanut, rubber, pepper, cashewnut, tapioca, coffee, tea, cardamom, ginger, banana and other plantains. Together they accounted for 84.83 percent of gross cropped area in 1960-61. It declined to 82.73 percent in 2009-10. It would be noted that percentage of area under cashewnut has shown increasing trend during the sixties and seventies. During eighties, nineties and the last decade the area under cashewnut has declined. The area under cashewnut gained the maximum area in 1983-84 after which it declined and reached the level of 1.84 percent in 2009-10.

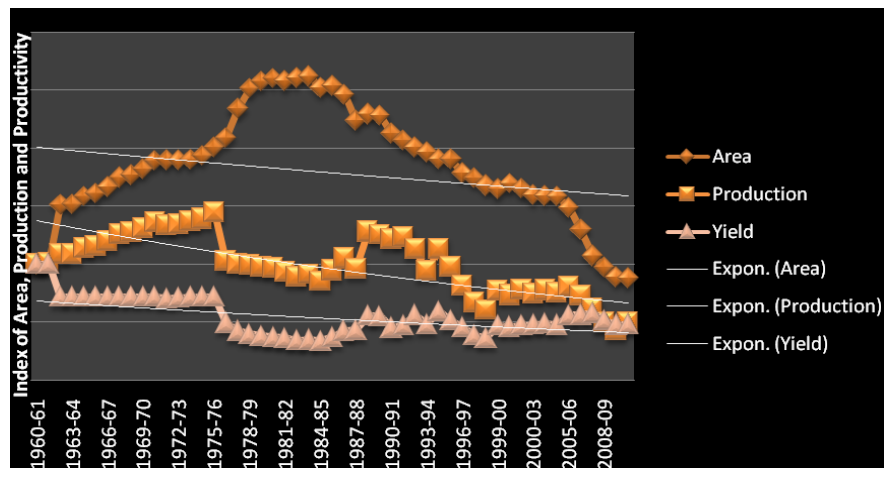

Fig 1. Area, Production and Productivity of Cashewnut in Kerala

Table.6. Compound Growth Rates of Area, Production and Productivity of Cashewnut in Kerala in Different Periods.

\begin{tabular}{|c|c|c|c|c|c|c|c|}
\hline $\begin{array}{l}\text { Sl. } \\
\text { No. }\end{array}$ & Item & $\begin{array}{c}\text { Period } \\
\text { I }\end{array}$ & $\begin{array}{c}\text { Period } \\
\text { II }\end{array}$ & $\begin{array}{c}\text { Period } \\
\text { III }\end{array}$ & $\begin{array}{c}\text { Period } \\
\text { IV }\end{array}$ & $\begin{array}{c}\text { Period } \\
\mathrm{V}\end{array}$ & $\begin{array}{l}\text { Overall } \\
\text { Period }\end{array}$ \\
\hline 1 & Area & 6.456 & 3.783 & -1.767 & -2.832 & -6.405 & -0.151 \\
\hline 2 & Production & 3.123 & -4.341 & $\begin{array}{c}* \\
3.359\end{array}$ & $\begin{array}{c}- \\
7.461\end{array}$ & $\begin{array}{c}* * * \\
-3.655\end{array}$ & -1.238 \\
\hline 3 & Productivity & $\begin{array}{c}* * \\
-3.133 \\
\end{array}$ & -7.848 & 5.208 & $\begin{array}{c}* \\
* \\
-2.218\end{array}$ & $\begin{array}{c}* \\
2.521 \\
\end{array}$ & -1.098 \\
\hline
\end{tabular}

* - Significant at probability level 0.01, ** - Significant at probability level 0.03

*** - Significant at probability level 0.05

Period I (1960-61 to 1969-70), II (1970-71 to 1979-80), III (1980-81 to 1989-90), IV (1990-91 to 1999-00), V (2000-01 to 2009-10), Overall Period (1960-61 to 2009-10).

Source: - Karunakaran N (2013), "Growth Trends of Area, Production and Productivity of Crops in Kerala: A Fifty Years Experience”, Southern Economist, Vol. 51, No. 17, pp: 35-38. 
Table. 6 reveals that cashewnut crop showed negative growth rate in area at increasing rate during the different decades from 1960-61 to 2009-10 in Kerala. During the first period, the crop recorded significant growth in area and production. From period II onwards the crop accounted deceleration in area and production. The compound growth rates of these two crops were negative during these periods. During period IV highest negative growth rate was observed in the case of cashewnut production in Kerala. One significant feature observed from Table.6 is that cashewnut recorded negative compound growth rates during 2000-01 to 200910 time period. Table also shows the poor, fluctuating and negative rate of growth of productivity of the crop in Kerala during the different periods.

Table.7. Decomposition of output growth of Cashewnut crops in Kerala.

\begin{tabular}{|c|c|c|c|c|c|c|c|c|c|}
\hline $\begin{array}{l}\mathrm{Sl} \\
\text { No } \\
\end{array}$ & Period & $\mathrm{c}_{0}$ & $\mathrm{y}_{0}$ & $\mathrm{w}_{0}$ & $c_{t}$ & $\mathrm{y}_{\mathrm{t}}$ & $\mathrm{w}_{\mathrm{t}}$ & $\mathrm{A}_{0}$ & $\mathrm{~A}_{\mathrm{t}}$ \\
\hline 1 & $\begin{array}{c}\text { Period } \\
\text { I }\end{array}$ & 2.31 & 1558 & 77.32 & 3.39 & 1122 & 146.42 & $\begin{array}{c}2349 \\
(\text { '000 } \\
\text { hectare) }\end{array}$ & $\begin{array}{c}2916 \\
\text { ('000 } \\
\text { hectare) }\end{array}$ \\
\hline 2 & $\begin{array}{c}\text { Period } \\
\text { II }\end{array}$ & 3.50 & 1122 & 139.80 & 4.90 & 591 & 582.73 & $\begin{array}{c}2933 \\
\text { ('000 } \\
\text { hectare) }\end{array}$ & $\begin{array}{r}2854 \\
(' 000 \\
\text { hectare) } \\
\end{array}$ \\
\hline 3 & $\begin{array}{c}\text { Period } \\
\text { III }\end{array}$ & 4.90 & 580 & 731.91 & 4.10 & 859 & 1177.51 & $\begin{array}{c}2885 \\
\text { ('000 } \\
\text { hectare) }\end{array}$ & $\begin{array}{l}3019 \\
(' 000 \\
\text { hectare) } \\
\end{array}$ \\
\hline 4 & $\begin{array}{c}\text { Period } \\
\text { IV }\end{array}$ & 3.83 & 702 & 1379.90 & 2.96 & 733 & 3638.50 & $\begin{array}{c}3020 \\
\text { ('000 } \\
\text { hectare) }\end{array}$ & $\begin{array}{r}3017 \\
(' 000 \\
\text { hectare) } \\
\end{array}$ \\
\hline 5 & $\begin{array}{c}\text { Period } \\
\text { V }\end{array}$ & 3.05 & 718 & 2368.81 & 1.96 & 800 & 3665.09 & $\begin{array}{c}3022 \\
\text { ('000 } \\
\text { hectare) }\end{array}$ & $\begin{array}{r}2669 \\
(' 000 \\
\text { hectare) } \\
\end{array}$ \\
\hline 6 & $\begin{array}{l}\text { Overall } \\
\text { Period }\end{array}$ & 2.31 & 1558 & 77.32 & 1.96 & 800 & 3665.09 & $\begin{array}{c}2349 \\
\text { ('000 } \\
\text { hectare) }\end{array}$ & $\begin{array}{r}2669 \\
(' 000 \\
\text { hectare) } \\
\end{array}$ \\
\hline
\end{tabular}

$\mathrm{c}_{0}, \mathrm{c}_{\mathrm{t}}$ - Share of area (Percentage) of the total cropped area, $\mathrm{y}_{0}, \mathrm{y}_{\mathrm{t}}$ - Output in $\mathrm{Kg} /$ hectare, $\mathrm{w}_{0}, \mathrm{w}_{\mathrm{t}}-$ Price per quintal (in Rupees).

Period I (1960-61 to $1969-70)$, II (1970-71 to 1979-80), III (1980-81 to 1989-90), IV (1990-91 to 1999-00), V (2000-01 to 2009-10), Overall Period (1960-61 to 2009-10).

Source: - Computed from (i) Statistics for planning (various issues), Department of Economics and Statistics, Govt. of Kerala, Thiruvananthapuram. (ii) Economic Review (various issues), State Planning Board, Govt. of Kerala, Thiruvananthapuram. 
Table.7 and 8 gives the decomposition of the increase in the value of output of cashewnut crop in Kerala for periods I to V. Taking period I and II first, it is noted in serial number 1 of Table. 8 that there is percentage increase in the value of output of the crop and after that decrease in the value of output. The main divisions into real component and monetary components have been given in serial number 6 and 11 respectively. For cashewnut, monetary growth is greater than real growth; in period $\mathrm{V}$ negative monetary growth was observed over real growth.

Table.8. Overall Growth of Cashewnut Cultivation in Kerala in Different periods. (In percentages)

\begin{tabular}{|c|l|c|c|c|c|c|c|}
\hline \multirow{2}{*}{$\begin{array}{c}\text { Sl. } \\
\text { No. }\end{array}$} & \multicolumn{1}{|c|}{ Elements } & \multicolumn{6}{c|}{ Period } \\
\cline { 3 - 8 } & & I & II & III & IV & V & OP \\
\hline 1 & Increase in value of output & 117.73 & 318.89 & 74.54 & 64.56 & -36.42 & 1100.35 \\
\hline 2 & Area effect & 31.07 & 11.38 & -21.08 & -35.10 & 124.08 & -0.14 \\
\hline 3 & Yield effect & -19.32 & -20.21 & 71.28 & 5.29 & -19.09 & -2.48 \\
\hline 4 & Cropping pattern effect & 32.20 & 17.09 & -24.19 & -27.21 & 59.74 & -0.77 \\
\hline 5 & Interaction effect & -9.01 & -8.09 & -11.64 & -1.20 & 0.77 & 0.38 \\
\hline 6 & Real Growth (2+3+4+5) & 34.94 & 0.17 & 14.37 & -58.22 & 165.50 & -3.01 \\
\hline 7 & Pure price effect & 61.56 & 135.38 & 90.22 & 196.06 & -91.46 & 236.46 \\
\hline 8 & Price Yield effect & -17.23 & -64.07 & 30.99 & 8.66 & -10.45 & -115.04 \\
\hline 9 & $\begin{array}{l}\text { Price cropping pattern } \\
\text { effect }\end{array}$ & 28.78 & 54.15 & -28.49 & -44.53 & 32.68 & -35.83 \\
\hline 10 & Total Interaction effect & -8.05 & -25.63 & -7.09 & -1.97 & 3.73 & 17.42 \\
\hline 11 & $\begin{array}{l}\text { Monetary Growth } \\
\text { (7+8+9+10) }\end{array}$ & 65.06 & 99.83 & 85.63 & 158.22 & -65.50 & 103.01 \\
\hline 12 & Total (6+11) & 100.00 & 100.00 & 100.00 & 100.00 & 100.00 & 100.00 \\
\hline
\end{tabular}

Period I (1960-61 to $1969-70)$, II (1970-71 to $1979-80)$, III (1980-81 to 1989-90), IV (1990-91 to 1999-00), V (2000-01 to 2009-10), Overall Period- OP (1960-61 to2009-10).

Source: - Computed from Table.7.

A comparison between the different periods clearly shows that pure price effect is the main component dominating the increase in the value of output of the cashewnut crop in Kerala. From the above analysis, it is revealed that the increase in the value of output of the crop presented in the overall period from 1960-61 to 2009-10, is monetary growth in nature rather than real growth. 


\section{Conclusion}

Cashew is predominantly a small holder crop in India and about 70 percentage of cashewnut are grown by small scale farmers. The number of cashew processing units in India has increased rapidly over the last four decades. Cashew is the major plantation crop that is not regulated by an autonomous board. Other plantations, such as tea, coffee, cardamom, and rubber have efficient and autonomous boards, and as a result have experienced much faster growth in productivity than cashew. Cashew is one of the most neglected plantation crops in India despite its status as a major source of foreign exchange.

Area, production and productivity of cashew cultivation have been showing decreasing trend in Kerala. During the overall period, the crop shows negative growth rates in area, production and productivity. Decline in area and yield growth rate was responsible for the negative growth rate in production for cashewnut. The area under cashew cultivation has started coming down over the years and unless there are concerted efforts by the government to create awareness among cashew growers on scientific cultivation methods, there will be conversion of cashew plantations into rubber plantations. A major reason for the unpredictability of cashew cultivation is the fact that nearly 70 percent of the cashew trees in the state are aged, local varieties, which start yielding late in the season. Climate change also affects cashew cultivation. Coincidence of excessive rain fall and high relative humidity with flowering may result in flower or fruit drop and heavy incidence of fungal disease. It is observed that there are 30 species of insects affecting cashew, out of these tea mosquito, stem and root borer and fruit and nut borer are the major pests, which are reported to cause around 30 percent loss to the yield.

The growth of agricultural output in the state like that of other parts of India is influenced by the gross cropped area, productivity and level of prices. The increase in agricultural output is decomposed into real and monetary components. The real component includes area effect, yield effect, cropping pattern effect and interaction effect. The monetary elements consist of the pure 
price effect, price yield effect, price cropping pattern effect and total interaction effect.

From the analysis of the overall growth of crop output into real and monetary components, during different decades in the reference period, the general conclusions derived are: (i) there are fluctuations in the overall growth of cashewnut crop output in Kerala over different decades, (ii) there is a perceptible increase in the monetary growth and decline in the real growth of crop output, (iii) price factor is the major element in determining the relative contribution of different elements to the growth of crop output and (iv) overall growth of crop output of cashewnut is monetary growth in nature rather than real growth.

From the results of the study it is concluded that cashew cultivation has been showing an increasing trend in India and decreasing trend in Kerala and there is a change in cropping pattern from cashew cultivation to rubber cultivation among farmers because of crop loss and fall in price of cashewnut and attractive or charming price of rubber.

\section{References}

Ashok Parikh. (1966). State wise growth rates in Agricultural output, an economic analysis, Artha Vijnana, 8( 1), 1-52.

Bhalla, G. S \& Alagh, Y. K. (1979). Performance of Indian Agriculture: a district wise study, Planning Commission, Govt. of India, and Published by Sterling Publishers, New Delhi.

Bhat and Raviprasad (2006). 'Endosulphan and Carbonyl Residues in Cashew kernels', Journal of Plantation Crops, Indian Society for Plantation Crops, 34 (3), 5-8

Dashora, S., Dhaka, J. M \& Agarwal, N. J. (2000). Growth in production of important pulse crops in Rajasthan, Agricultural Situation in India, $52(8)$.

Dayal R (1966) .Agricultural growth rates and their components, Indian Journal of Agricultural Economics, 21( 4),227-237.

Dharm Narain (1977), Growth of Productivity in Indian Agriculture, Indian Journal of Agricultural Economics, 32 (1), 1-44.

Divya, Raman, S., Pushpalatha, P.B. \& Narayanan Kutty, M.C. (2002). Variation in processing qualities of cashew nut in relation to damage by insect pests, Journal of Tropical Agriculture Directorate of 
Extension, Kerala Agricultural University, Trissur, Kerala, 40, 3538.

Govt. of Kerala (2010), Economic Review, State Planning Board, Thiruvananthapuram, Kerala, 19-41.

Govt. of Kerala (2011), Economic Review, State Planning Board, Thiruvananthapuram, Kerala, 19-49.

Kannan, K. P. (1983), “Cashew Development in India - Potentialities and constraints", Center for Development Studies, Thiruvananthapuram.

Kannan, K. P. and Pushpangadan, A. (1988), Agricultural Stagnation in Kerala: An Exploratory analysis, Economic and Political Weekly, 23(39), A120-A128.

Karunakaran, N. (2013), Growth Trends of Area, Production and Productivity of Crops in Kerala: A Fifty Years Experience, Southern Economist, 51(17), 35-38.

Kaushik, K. K. (1993), Growth of Agricultural Production: a component analysis, Agricultural Transformation in a Developing Economy, Kanishka Publishers and Distributors, Delhi, 216-238.

Kurian, C. T. and Joseph James. (1979), Economic changes in Tamilnadu: 1960-70, A regionally and functionally Disaggregated analysis, Allied Publishers Pvt. Ltd, New Delhi, pp: 92-103.

Kurosaki, Takashi. (2002), Agriculture in India and Pakistan, 1900-95: A further note, Economic and Political Weekly, 37(30), July 27 - Aug 2.

Lakshmi, K. R. and Pal, T. K. (1988), "Growth of crop output in Kerala”, Agricultural Situation in India, 43(9), 789.

Mahesh, R. (1999), Causes and consequences of changes in cropping pattern: A location-specific study, Discussion paper series No.11, Centre for Development Studies, Thiruvananthapuram, 1-56.

Mani, K. P. (2009), Cropping pattern in Kerala - spatial inter-temporal analysis, Kerala Economy: Trends during the post-reform period (Ed), by Rajan K, Serials Publications, New Delhi, 64-84.

Minhas, B. S and Vaidyanathan, A. (1965), Growth of crop output in India, 1951-54 to 1958-61: An analysis by component elements, Journal of the Indian Society of Agricultural Statistics, 17 (2), 230-252.

Mishra, V. N. (1971), Growth of crop output in Gujarat: A component analysis. Anvesak, 1(1), 1-15.

Mohandas, M. (2005), Agricultural Development in Kerala, in Kerala Economy- Trajectories, Challenges and Implications (Ed), by Rajasenan D and Gerald de Groot, 126-127. 
Nair, M. K., Bhaskara Rao, E. V. V., Nambiar, K. K. N, and Nambiar, M. C. (1979), Cashew, Central Plantation Crops Research Institute (CPCRI), Kasaragod

Pradeep, Kumar, T., Suma, B., Jyothi, Bhasker. and Satheeshan, K. N. (2008), Management of Horticultural crops, Part II, New India Publishing Agency, Kerala Agricultural university, Trissur.

Prasad, Rao. GSLHV (2002), Climate and Cashew, Kerala Agricultural University, Mannuthy, Trissur, Kerala

Rajender, Sondhi and Karam, Singh. (1975), Component Analysis of Food grain economy of India, Journal of Social and Economic Studies, $3(2), 255-270$.

Raju, G. (2006), Traditional Industries of India in the Globalized world Cashew Industry. New Century Publications, New Delhi, India

Ranade, C. G. (1980), Impact of cropping pattern on agricultural production, Indian Journal of Agricultural Economics, 35(2), 85-86.

Sikka, B. K and Vaidya, C. S. (1985), Growth rates and cropping pattern changes in agriculture in Himachal Pradesh, Agricultural Situation in India, 39(11), 843-844.

Sini, A. and Nair. C. K. (2007), The nutrition and health aspects of cashewnut, Cashew Bulletin, Cashew Export Promotion Council of India, Ernakulam, XLV, (12), 7-9

Varghese, P. K. (2004), Trend analysis of area, production, productivity and price behaviour of cardamom in Kerala, Indian Journal of Agricultural Economics, 39, October - November

Varghese, P. K. (2007), Economics of cardamom cultivation in Kerala", Indian Journal of Agricultural Economics, 62(1), 99-112.

Vidhya, Sagar. (1977), A component analysis of Growth of agricultural productivity in Rajasthan: 1956-61 to 1969-74, Indian Journal of Agricultural Economics, 32 (1), 109-119. 